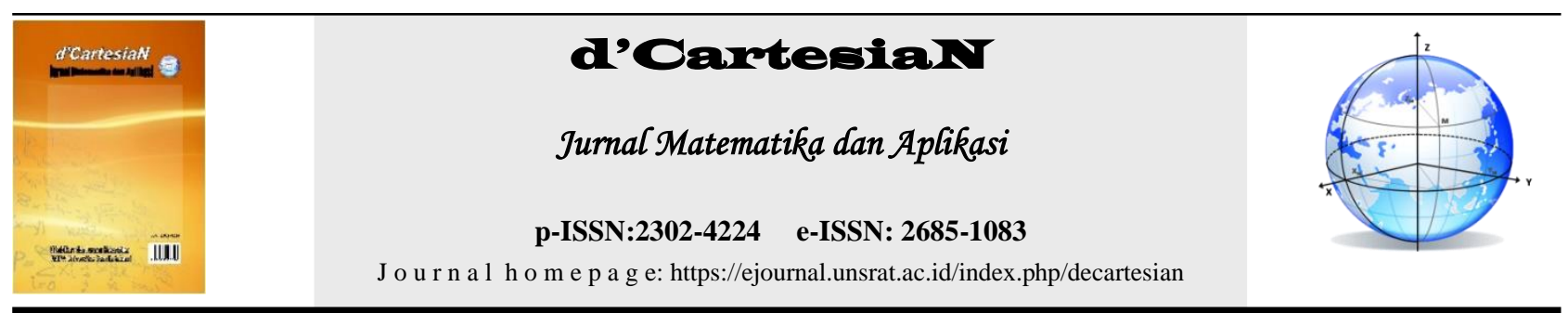

\title{
Penerapan Metode Double Moving Average Untuk Meramalkan Hasil Produksi Tanaman Padi di Provinsi Gorontalo
}

\author{
Hendra Andrianto Yusuf 1*, Ismail Djakaria1, Resmawan'
}

${ }^{1}$ Jurusan Matematika, Fakultas Matematika dan IPA, Universitas Negeri Gorontalo

Jl. Prof. Dr. Ing. B. J. Habibie, Tilongkabila, Kabupaten Bone Bolango, Gorontalo 96119, Indonesia

*Corresponding author: hendra.yusuf2906@gmail.com

\begin{abstract}
ABSTRAK
Artikel ini membahas tentang metode double moving average untuk mengetahui hasil ramalan produksi tanaman padi di Provinsi Gorontalo. Metode double moving average merupakan metode rata-rata bergerak linier yang digunakan untuk mengatasi data deret waktu dengan pola yang cenderung mengalami trend linear. Berdasarkan pola data hasil produksi tanaman padi, menunjukkan bahwa pola data tersebut mengalami peningkatan setiap tahunnya dan dapat diidentifikasi bahwa data berpola trend. Hasil penelitian ini menunjukan bahwa model terbaik untuk meramalkan hasil produksi tanaman padi diperole MA $(2 \times 2)$ dengan model persamaan adalah $\mathrm{F} 18+\mathrm{p}=331692+(-5373) \times \mathrm{m}$ dan nilai tingkat akurasi yaitu measure absolute persenrage error (MAPE) sebesar 5.3537. Sehingga diperoleh hasil peramalan 5 tahun ke depan yaitu tahun 2019 sebesar 326318.5 Ton, 2020 sebesar 32094.5 Ton, dan seterusnya sampai tahun 2023 sebesar 304826.5 Ton.
\end{abstract}

\section{INFO ARTIKEL}

Diterima : 11 Mei 2020

Diterima setelah direvisi : 20 Oktober 2020

Tersedia online : 2 November 2020

\section{KATA KUNCI:}

Peramalan;

Time Series,

Double Moving Average

\begin{tabular}{|c|c|}
\hline \multirow{10}{*}{$\begin{array}{l}\text { ABSTRACT } \\
\text { This article discusses the double moving average method to find out the results of the rice } \\
\text { production forecast in Gorontalo Province. The double moving average method is a linear moving } \\
\text { average method used to overcome time series data with patterns that tend to experience linear } \\
\text { trends. Based on the data patterns of rice crop production, shows that the data patterns have } \\
\text { increased every year and can be identified that the data patterned trends. The results of this study } \\
\text { indicate that the best model for predicting the yield of rice is obtained MA }(2 \times 2) \text { with the equation } \\
\text { model is F18 }+\mathrm{p}=331692+(-5373) \times \text { m and the value of the accuracy level is the measure absolute } \\
\text { percent error (MAPE) of } 5.3537 \text {. So that the forecast results obtained for the next } 5 \text { years are } 2019 \\
\text { amounting to } 326318.5 \text { tons, } 2020 \text { amounting to } 32094.5 \text { tons, and so on until } 2023 \text { amounting to } \\
304826.5 \text { tons. }\end{array}$} & ARTICLE INFO \\
\hline & May 2020 \\
\hline & Accepted after revision : 20 \\
\hline & 2020 \\
\hline & Available online : 2 November \\
\hline & 20 \\
\hline & KATA KUNCI: \\
\hline & Forecasting; \\
\hline & \\
\hline & Double Movir \\
\hline
\end{tabular}

\section{PENDAHULUAN}

Peramalan (forecasting) adalah proses untuk memperkirakan beberapa kebutuhan di masa mendatang yang meliputi kebutuhan dalam ukuran kualitas barang, waktu dan lokasi yang dibutuhkan dalam memenuhi permintaan barang ataupun jasa [1]. Menurut [2] peramalan (forecasting) adalah seni dan ilmu untuk memperkirakan kejadian di masa depan. Fungsi peramalan terlihat pada saat pengambilan keputusan. Keputusan yang baik adalah keputusan yang berdasarkan atas kejadian apa yang akan terjadi pada waktu keputusan itu dilaksanakan. Apabila kurang tepat hasil ramalan yang kita peroleh, maka masalah peramalan juga merupakan suatu masalah yang selalu kita hadapi [1]. Dalam melakukan peramalan terdapat beberapa metode yang umum dipakai. Secara garis besar metode deret waktu (time series) dikelompokan menjadi metode average yaitu (single moving average dan double moving average), metode smoothing yaitu (single exponential smoothing, double exponential smoothing dari Brown dan Holt) dan metode regresi yaitu time series regression [3]. Hal penting yang harus diperhatikan dalam metode time series adalah menentukan jenis pola data. Beberapa jenis pola data yang harus diperhatikan yaitu pola data trend, siklis, musiman, dan horizontal [4].

Pada penelitian terdahulu oleh [5] tentang melakukan peramalan permintaan kebutuhan tenaga kerja pada perusahaan Outsourcing menggunakan algoritma simple moving average. Dalam penelitian ini dilakukan pengambilan data awal jumlah tenaga kerja mulai dari januari 2015 - juni 2016. Hasil penelitian menunjukan bahwa algoritma simple moving average dapat diterapkan untuk proses peramalan permintaan tenaga kerja dikarenakan penerapan algoritma yang cukup sederhana dengan menggunakan sejumlah data actual permintaan yang baru dapat membangkitkan nilai ramalan dimasa yang akan datang.

Pada penelitian yang dilakukan oleh [6] tentang peramalan persewaan kaset video dengan menggunakan metode Moving Average. Dari penelitian ini disimpulkan bahwa hasil peramalan persewaan kaset video dari minggu ke-1 sampai minggu ke-15 dengan menggunakan metode Double Moving Average diperoleh model persamaan untuk periode kedepan yaitu $\mathrm{F}_{\mathrm{t}+\mathrm{p}}=772+5 \mathrm{p}$. 
Terdapat penelitian yang dilakukan oleh [1] tentang perbandingan metode double moving average dan double exponential smooting pada peramalan bahan medis habis pakai. Pada penelitian ini dilakukan dengan mengambil sampel yaitu data jarum sumpit (spuit) 3 ml periode 1 januari sampai 30 juni 2017. Hasil penelitian ini menunjukan bahwa metode double moving average lebih akurat dibandingkan dengan metode double exponential smoothing.

Penelitian ini membahas tentang peramalan hasil produksi tanaman padi dengan menggunakan metode double moving average. data deret waktu yang digunakan adalah hasil produksi tanaman padi di Provinsi Gorontalo dari tahun 2001-2018, karena pergerakan data hasil produksi tersebut cenderung mengalami peningkatan dari tahun ke-tahun dan dapat di identifikasi bahwa data berpola (trend). Alasan menggunakan metode double moving average karena agar lebih mengakomodir adanya trend pada data hasil produksi tanaman padi. Peramalan disajikan untuk beberapa langkah kedepan, serta dilengkapi dengan nilai ukuran ketepatan peramalan yaitu MAPE.

Suatu cara peramalan data deret waktu yang memiliki trend linier adalah dengan menggunakan ratarata bergerak ganda (double moving average) [4]. Ratarata bergerak ganda atau dikenal dengan rata-rata bergerak linier (linear moving average) digunakan untuk mengatasi data deret waktu dengan pola yang cenderung mengalami trend linear [7]. Rata-rata bergerak ganda merupakan salah satu metode rata-rata bergerak yang menggunakan data single moving average pada waktu tertentu dengan penyesuaian antara rata-rata bergerak pertama dan rata-rata bergerak kedua serta penyesuaian trend [8].

Teknik dari metode double moving average dimana kelompok rata-rata bergerak pertama dihitung, dan kemudian dihitung kelompok rata-rata bergerak kedua [9]. Rata-rata bergerak ganda merupakan ratarata bergerak dari rata-rata bergerak, dan disimbolkan dengan $(k \times k)$, artinya rata-rata bergerak sebanyak $k$ periode dari rata-rata bergerak sebanyak $k$ periode [3]. Pada metode rata-rata bergerak tidak ada dasar obyektif untuk penentuan banyaknya orde rata-rata bergerak [7].

[3] Menjelaskan setiap metode peramalan memiliki tingkat ketelitian masing-masing yang harus dipertimbangkan. Oleh karena itu, harus dipilih metode yang dapat meminimumkan kesalahan peramalan. Semakin kecil nilai error, maka akan semakin akurat hasil ramalan yang kita peroleh. Mean absolute Percentage error (MAPE) merupakan suatu perhitungan evaluasi, MAPE digunakan untuk mengukur seberapa tepat atau akurat suatu prediksi yang sering digunakan [10]. MAPE akan mengukur ratarata dari error absolute sebagai persentase dari nilai rata-rata error rate absolute periode data aktual.

Penelitian ini bertujuan untuk menentukan hasil peramalan produksi tanaman padi untuk 5 tahun kedepan dengan metode double moving average.

\section{METODE PENELITIAN Variabel Penelitian}

Pada penelitian ini, variabel yang digunakan adalah hasil produksi tanaman padi per-tahun yang diambil pada interval Tahun 2001 - 2018.

\section{Sumber Data}

Data yang digunakan pada penelitian ini adalah data sekunder berupa time series. Data tersebut diperoleh dari Dinas Pertanian Provinsi Gorontalo.

\section{Populasi dan Sampel}

Populasi yang digunakan dalam penilitian ini adalah data hasi produksi tanaman padi periode Tahun 2001 - 2018. Adapun sampel yang diambil sebanyak jumlah populasi yang digunakan.

\section{Teknik Penarikan Sampel}

Pada penelitian ini, teknik penarikan sampel yang digunakan adalah sampling jenuh. Sampling jenuh merupakan teknik penentuan sampel dimana semua anggota populasi digunakan sebagai sampel.

\section{Teknik Analisis Data}

Tahapan analisis data yang dilakukan dalam penelitian ini adalah:

a. Mengidentifikasi pola data time series.

b. Menentukan nilai rata-rata bergerak pertama.

c. Menentukan nilai rata-rata bergerak kedua.

d. Menentukan besarnya nilai konstanta $\left(a_{t}\right)$.

e. Menentukan besarnya nilai koefisien trend $\left(b_{t}\right)$.

f. Menentukan model terbaik berdasarkan kriteria ukuran keterpatan peramalan MAPE.

g. Menetukan hasil ramalan untuk periode mendatang.

Untuk memudahkan dalam hal komputasi, analisis data dilakukan dengan bantuan software Microsoft Excel.

\section{HASIL DAN PEMBAHASAN}

\section{Identifikasi Pola Data}

Penelitian ini menggunakan data hasil produksi tanaman padi. Data tersebut merupakan data time series. Plot data time series tingkat hasil produksi tanaman pangan disajikan pada Gambar 1.

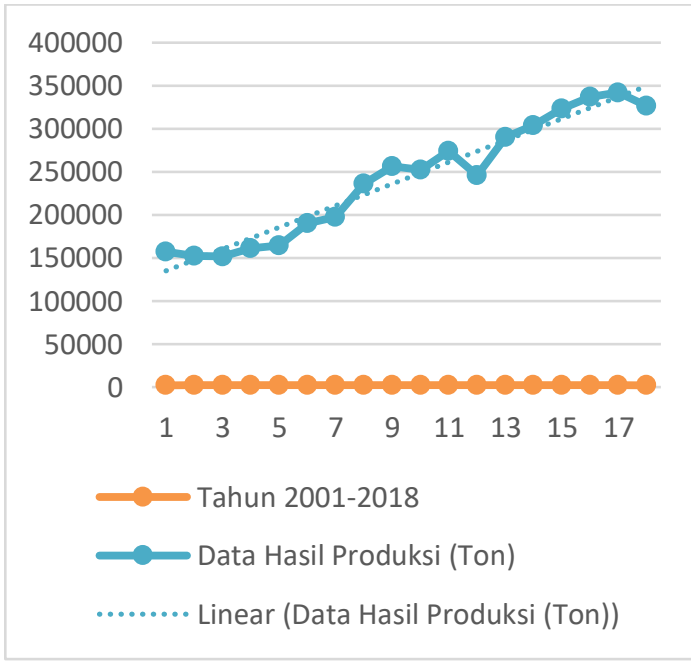

Gambar 1. Data Hasil Produksi Tanaman Padi Tahun 2001-2018 
Gambar 1 menunjukkan pergerakan data hasil produksi tanaman padi mengalami peningkatan. Hasil produksi minimum sebesar 151.837 Ton terjadi pada tahun 2003, sedangkan hasil produksi maksimum sebesar 342.172 Ton terjadi pada tahun 2017. Sehingga dapat diidentifikasi bahwa data berpola trend.

\section{Perhitungan Double Moving Average}

Adapun langkah-langkah perhitungan dengan metode double moving average sebagai berikut.

a. Menentukan nilai rata-rata bergerak pertama dengan menggunakan persamaan berikut.

$$
M_{t}^{\prime}=\frac{X_{t}+X_{t-1}+X_{t-2}+\cdots+X_{t-N-1}}{N}
$$

1. Untuk $t=2$

$$
M_{t}^{\prime}=\frac{15227+157537}{2}=154882
$$

2. Untuk $t=3$

$$
M_{t}^{\prime}=\frac{151837+152227}{2}=152032
$$

Dan seterusnya sampai pada perhitungan $M_{t}^{\prime}$ untuk $t=18$

3. Untuk $t=18$

$$
M_{18}^{\prime}=\frac{326584+342172}{2}=33478
$$

Perhitungan selengkapnya dapat dilihat pada Tabel 1.

b. Menentukan nilai rata-rata bergerak kedua dapat menggunakan persamaan berikut.

$$
M_{t}^{\prime \prime}=\frac{M_{t}^{\prime}+M_{t-1}^{\prime}+M_{t-2}^{\prime}+\cdots+M_{t-N-1}^{\prime}}{N}
$$

1. Untuk $t=3$

$$
M_{t}^{\prime \prime}=\frac{152032+154882}{2}=153457
$$

2. Untuk $t=4$

$$
M_{t}^{\prime}=\frac{156330+152032}{2}=154181
$$

Dan seterusnya sampai pada perhitungan $M_{t}^{\prime}$ untuk $t=18$

3. Untuk $t=18$

$$
M_{18}^{\prime \prime}=\frac{339751+334378}{2}=337064,5
$$

Perhitungan selengkapnya dapat dilihat pada Tabel 1.

c. Menentukan besarnya nilai konstanta $\left(a_{t}\right)$ dengan menggunakan persamaan berikut.

$$
a_{t}=2 M_{t}^{\prime}-M_{t}^{\prime \prime}
$$

1. Untuk $t=3$

$$
\begin{aligned}
& a_{t}=2 \times(152032)-153475 \\
& =150607
\end{aligned}
$$

2. Untuk $t=4$

$$
\begin{aligned}
& a_{t}=2 \times(156330)-154181 \\
& =158479
\end{aligned}
$$

Dan seterusnya sampai pada perhitungan $M_{t}^{\prime}$ untuk $t=18$

3. Untuk $t=18$

$$
\begin{aligned}
& a_{t}=2 \times(334378)-337064,5 \\
& =331691,5
\end{aligned}
$$

Perhitungan selengkapnya dapat dilihat pada Tabel 1.

d. Menentukan besarnya nilai koefisien trend $\left(b_{t}\right)$ dengan menggunakan persamaan berikut.

\begin{tabular}{|c|c|c|c|c|c|c|}
\hline Periode & $X_{t}$ & $M_{t}^{\prime}$ & $M_{t}^{\prime \prime}$ & $a_{t}$ & $b_{t}$ & Forecast \\
\hline 1 & 157537 & & & & & \\
\hline 2 & 152227 & 154882 & & & & \\
\hline 3 & 151837 & 152032 & 153457 & 150607 & -2850 & \\
\hline 4 & 160823 & 156330 & 154181 & 158479 & 4298 & 147757 \\
\hline 5 & 164210 & 162517 & 159423 & 165610 & 6186.5 & 162777 \\
\hline 6 & 190125 & 177168 & 169842 & 184493 & 14651 & 171796 \\
\hline 7 & 197779 & 193952 & 185560 & 202344 & 16784.5 & 199144 \\
\hline 8 & 236236 & 217008 & 205480 & 228535 & 23055.5 & 219129 \\
\hline 9 & 256217 & 246227 & 231617 & 260836 & 29219 & 251591 \\
\hline 10 & 252242 & 254230 & 250228 & 258231 & 8003 & 290055 \\
\hline 11 & 273773 & 263008 & 258619 & 267397 & 8778 & 266234 \\
\hline
\end{tabular}

1. Untuk $t=3$

$$
b_{t}=\frac{2}{N-1}\left(M_{t}^{\prime}-M_{t}^{\prime \prime}\right)
$$

$$
\begin{aligned}
& b_{t}=\frac{2}{2-1} \times(152032-153457) \\
& =-2850
\end{aligned}
$$

2. Untuk $t=4$

$$
\begin{aligned}
& b_{t}=\frac{2}{2-1} \times(156330-154181) \\
& =4298
\end{aligned}
$$

Dan seterusnya sampai pada perhitungan $M_{t}^{\prime}$ untuk $t=18$

3. Untuk $t=18$

$$
\begin{aligned}
& b_{t}=\frac{2}{2-1} \times(334378-337064,5) \\
& =-5373
\end{aligned}
$$

Perhitungan selengkapnya dapat dilihat pada Tabel 1.

e. Hasil perhitungan ramalan produksi tanaman padi dengan data aktual disajikan pada Tabel 1.

Tabel 1. Hasil Perhitungan Ramalan dengan Double Moving Average 


\begin{tabular}{rrrrrrr}
12 & 245666 & 259720 & 261364 & 258076 & -3288 & 276175 \\
13 & 290231 & 267949 & 263834 & 272063 & 8229 & 254788 \\
14 & 303627 & 296929 & 282439 & 311419 & 28980.5 & 280292 \\
15 & 323384 & 313506 & 305217 & 321794 & 16576.5 & 340400 \\
16 & 337330 & 330357 & 321931 & 338783 & 16851.5 & 338370 \\
17 & 342172 & 339751 & 335054 & 344448 & 9394 & 355634 \\
18 & 326584 & 334378 & 337065 & 331692 & -5373 & 353842 \\
\hline
\end{tabular}

Berdasarkan Tabel 1 dapat diketahui nilai perhitungan rata-rata bergerak pertama pada periode $t=2$ sebesar 154.882 , nilai rata-rata bergerak kedua pada periode $t=3$ sebesar 153.457, nilai $a_{t}$ pada periode $t=3$ sebesar -2850 dan seterusnya sampai pada periode $t=$ 18.

f. Menentukan nilai orde waktu terbaik dipilih berdasarkan nilai MAPE yang paling kecil dengan menggunakan persamaan berikut.

$$
M A P E=\left(\frac{1}{N}\right) \sum_{t=1}^{n} \frac{\left|X_{t}-F_{t}\right|}{X_{t}} \times 100 \%
$$

Hasil perhitungan nilai orde waktu disajikan pada Tabel 2.

Tabel 2. Hasil Perhitungan Ketepatan Metode Peramalan

\begin{tabular}{cc}
\hline Orde waktu $k$ & Nilai MAPE \\
\hline 2 & 5.3537 \\
3 & 5.5998 \\
4 & 6.2695 \\
\hline
\end{tabular}

Tabel 2 menunjukan hasil perhitungan ketepatan metode peramalan. Terlihat bahwa nilai orde wakt $k$ yang memiliki nilai $M A P E$ yang paling kecil yaitu $k=2$ sebesar 5,3537 .

g. Setelah menghitung besarnya nilai konstanta dan nilai koefisien trend maka diperoleh model MA $(2 \times 2)$ untuk meramalkan hasil produksi tanaman padi untuk periode ke depan adalah sebagai berikut:

$$
F_{18+m}=331692+(-5373) \times m
$$

Sehingga dapat dilakukan perhitungan hasil ramalan untuk 5 tahun ke depan. Hasil peramalan disajikan pada Tabel 3 .

Tabel 3. Hasil Ramalan Produksi Tanaman

\begin{tabular}{cc}
\multicolumn{2}{c}{ Padi (Ton) } \\
\hline Tahun & Ramalan \\
\hline 2019 & 326318.5 \\
2020 & 320945.5 \\
2021 & 315572.5 \\
2022 & 310199.5 \\
2023 & 304826.5 \\
\hline
\end{tabular}

h. Plot grafik dari data aktual dan hasil ramalan dengan metode double moving average ditampilkan pada gambar 2.

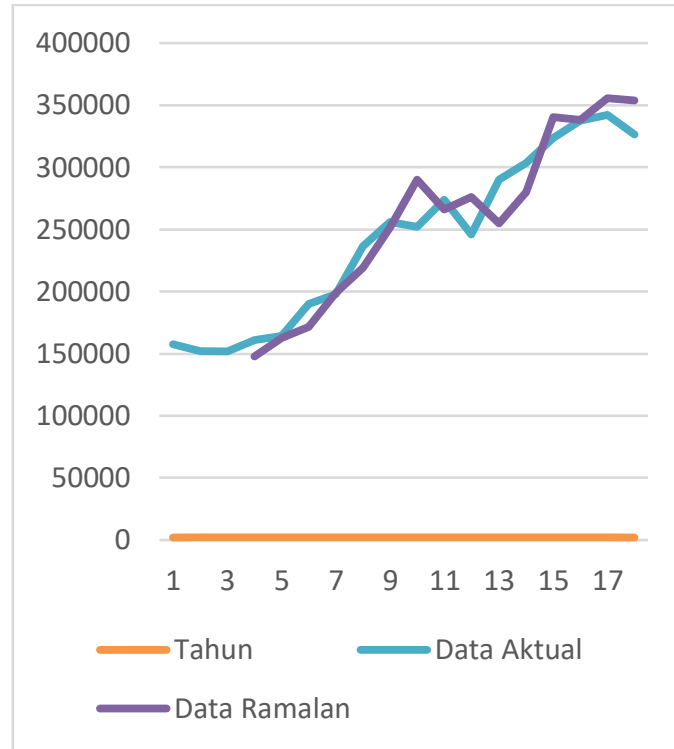

Gambar 2. Plot Data Aktual dan Hasil Ramalan

Berdasarkan Gambar 2 data aktual produksi tanaman padi ditunjukkan dengan garis berwarna biru, sementara data hasil ramalan ditunjukkan dengan garis berwarna ungu. Pada plot grafik dapat dilihat bahwa hasil peramalan dengan metode double moving average mampu mengikuti data aktual produksi tanaman padi.

\section{PENUTUP}

\section{Kesimpulan}

Dari hasil perhitungan metode double moving average diperoleh model untuk meramalkan hasil produksi tanaman padi adalah model $M A(2 \times 2)$ dengan nilai MAPE terkecil yaitu sebesar 5.3537 dengan model peramalan sebagai berikut:

$$
F_{18+m}=331692+(-5373) \times m
$$

Sehingga di peroleh hasil peramalan 5 tahun ke depan yaitu tahun 2019 sebesar 326318.5 Ton, 2020 sebesar 32094.5 Ton, dan seterusnya sampai tahun 2023 sebesar 304826.5 Ton.

\section{Saran}

Saat mengidentifikasi pola data harus lebih teliti karena akan berpengaruh pada metode peramalan yang akan digunakan. Seperti pada metode Double Moving Average yaitu data harus berpola trend sehingga data memenuhi asumsi.

\section{DAFTAR PUSTAKA}

[1] H. D. E Sinaga and N. Irawati, "Perbandingan Double Moving Average Dengan Double Exponential Smoothing Pada Peramalan Bahan Medis Habis Pakai,” JURTEKSI: Jurnal Teknologi 
dan Sistem Informasi., IV (2), pp. 197-204, Jun. 2018.

[2] J. Heizer and B. Render, Operations Management, (Tenth Edition). United States of America: Pearson, 2011.

[3] S. Makridakis, S. C. Wheelwright, and V. E. McGee V. E, Metode dan Aplikasi Peramalan, Edisi kedua, Terjemahan Hari Suminto. Jakarta: Binarupa Aksara, 1999.

[4] J. Hanke, E. Wichern, and W. Dean, Business Forecasting, $9^{\text {th }}$ Edition. United States of America: Pearson, 2014.

[5] H. Utari, Mesran, \& N. Silalahi, "Perancangan Aplikasi Peramalan Kebutuhan Tenaga Kerja Pada Perusahaan Outsourcing Menggunakan Algoritma Simple Noving Average,” Jurnal TIMES., V(2), pp. 1-5, 2016.

[6] D. I. Ruspriyanty, A. Sofro, and A. Oktaviarina, "Peramalan Persewaan Kaset Vidio Dengan Menggunakan Moving Average," Jurnal Ilmiah Matematika, 6 (2), pp. 75-8o, 2018.

[7] I. Hatimah, S. Wahyuningsih, and Sifriyani, "Perbandingan Metode Double Moving Average dan Pemulusan Exponensial Ganda dari Holt dalam Peramalan Harga Saham," Jurnal Exponensial, 4 (1), pp. 103-107, Mei. 2013.

[8] C. V. Hudiyanti, F. A. Bachtiar, and B. D Setiawan, "Perbandingan Double Moving Average dan Double Exponential Smoothing Untuk Peramalan Jumlah Kedatangan Wisatawan Mancanegara di Bandara Ngurah Rai," Jurnal Pengembangan Teknologi Informasi dan Ilmu Komputer, 3 (3), pp. 2667-2672, Maret. 2019.

[9] E. S. Seftiansyah, D. Yuniarti, and Syaripuddin, "Peramalan Kas Bank Centra Asia, Tbk Samarinda Tahun 2012 Dengan Menggunakan Metode Dekomposisi Dan Double Moving Average," Jurnal Exponensial, 4 (2), pp. 125-129, Nov 2013.

[10] S. Kim, and H. Kim, H, "A New Metric of Absolute Percentage Error for Intermittent Demand Forecasts," International Journal of Forecasting, 32 (3), pp. 669-679, 2016.

\section{BIODATA PENULIS}

Penulis bernama lengkap Hendra Andrianto Yusuf, Menempuh Pendidikan formal di TK Gogagoman Dumoga Timur pada tahun 2002, SDN 2 Dumoga Timur pada tahun 2003-2009, SMPN 3 Dumoga Timur 20092012, SMKN 1 Gorontalo Utara pada tahun 2012-2015, setelah itu penulis melanjutkan Pendidikan ke jenjang perguruan tinggi pada Program Studi S1 Statistika Jurusan Matematika dan Ilmu Pengetahuan Alam Universitas Negeri Gorontalo pada tahun 2015. 081340234382, hendra.yusuf2906@gmail.com. 